\title{
One Health, Fermented Foods, and Gut Microbiota
}

\author{
Victoria Bell ${ }^{1}$, Jorge Ferrão $^{2}$, Lígia Pimentel ${ }^{3}$, Manuela Pintado $^{3}$ and Tito Fernandes ${ }^{4, *(D)}$ \\ 1 Faculdade de Farmácia, Universidade de Coimbra, Azinhaga de Santa Comba, 3000-548 Coimbra, Portugal; \\ victoriabell1103@gmail.com \\ 2 Universidade Pedagógica, Rua João Carlos Raposo Beirão 135, Maputo 1000-001, Mozambique; \\ ljferrao@icloud.com \\ 3 CBQF-Centro de Biotecnologia e Química Fina, Escola Superior de Biotecnologia, \\ Universidade Católica Portuguesa, Rua Arquiteto Lobão Vital, Apartado 2511, 4202-401 Porto, Portugal; \\ lpimentel@porto.ucp.pt (L.P.); mpintado@porto.ucp.pt (M.P.) \\ 4 Faculdade de Medicina Veterinária, Universidade de Lisboa, 1300-477 Lisboa, Portugal \\ * Correspondence: profcattitofernandes@gmail.com; Tel.: +351-919927930
}

Received: 20 October 2018; Accepted: 29 November 2018; Published: 3 December 2018 updates

\begin{abstract}
Changes in present-day society such as diets with more sugar, salt, and saturated fat, bad habits and unhealthy lifestyles contribute to the likelihood of the involvement of the microbiota in inflammatory diseases, which contribute to global epidemics of obesity, depression, and mental health concerns. The microbiota is presently one of the hottest areas of scientific and medical research, and exerts a marked influence on the host during homeostasis and disease. Fermented foods and beverages are generally defined as products made by microbial organisms and enzymatic conversions of major and minor food components. Further to the commonly-recognized effects of nutrition on the digestive health (e.g., dysbiosis) and well-being, there is now strong evidence for the impact of fermented foods and beverages (e.g., yoghurt, pickles, bread, kefir, beers, wines, mead), produced or preserved by the action of microorganisms, on general health, namely their significance on the gut microbiota balance and brain functionality. Fermented products require microorganisms, i.e., Saccharomyces yeasts and lactic acid bacteria, yielding alcohol and lactic acid. Ingestion of vibrant probiotics, especially those contained in fermented foods, is found to cause significant positive improvements in balancing intestinal permeability and barrier function. Our guts control and deal with every aspect of our health. How we digest our food and even the food sensitivities we have is linked with our mood, behavior, energy, weight, food cravings, hormone balance, immunity, and overall wellness. We highlight some impacts in this domain and debate calls for the convergence of interdisciplinary research fields from the United Nations' initiative. Worldwide human and animal medicine are practiced separately; veterinary science and animal health are generally neither considered nor inserted within national or international Health discussions. The absence of a clear definition and subsequent vision for the future of One Health may act as a barrier to transdisciplinary collaboration. The point of this mini review is to highlight the role of fermented foods and beverages on gut microbiota and debate if the need for confluence of transdisciplinary fields of One Health is feasible and achievable, since they are managed by separate sectors with limited communication.
\end{abstract}

Keywords: nutrition; probiotics; fermented foods; health benefits

\section{Introduction}

The microbiota exerts a marked influence on the host during homeostasis linked with metabolic diseases in humans, but demonstration of causality remains a challenge [1].

Humans as hosts have co-evolved with microorganisms over millions of years, and each body habitat has a unique set of microorganisms shaping its microbiota [2]. 
These bacteria live on the skin, in the corners of the eyes, in the oral cavity, under fingernails, and most importantly, in the guts. Several perinatal determinants, such as caesarean section delivery, type of feeding, the use of antibiotics, gestational age or environment can affect the pattern of bacterial colonization, resulting in gut dysbiosis. The establishment and development of the gut microbiota over the lifecycle moved from the previous accepted dogma that the mammalian healthy placenta and foetus were germ-free and considered to be sterile, and that these conditions were critical to the developing newborn's immune system, to the actual knowledge that in utero humans are now known to harbour unique prenatal microbiomes [3,4].

Amniotic fluid may contain microorganisms, increasing the complexity of fetal microbiota, and having implications for the long-term health and susceptibility to disease, as placental microbiota could trigger immune responses in the fetus. Early gut microbiota settlement influences the maturation of the infant's immune system [5] and subsequent health, although the evidence in support of the "in utero colonization hypothesis" is considered extremely weak by some authors [6].

Health authorities are now becoming fully aware that one cannot be considered to be in good health without a well-balanced microbiota composition in the gut, our "forgotten organ" [7], and of the fundamental role of a diverse and healthy gut microbiota on the subsequent maintenance of future health and well-being of the host [8,9]. Indeed, although it is broadly mentioned that there are 10 times more cells from microorganisms in our bodies than there are human cells [10], this claim has been challenged, and others have estimated that the number of bacteria is similar to that of human cells [11].

Many species of bacteria, specifically those found in the invisible universe of the human microbiota, e.g., composed of nonpathogenic commensal microbiota from the Firmicutes, Bacteroidetes, Actinobacteria, Proteobacteria and Verrucomicrobia phyla [12], are unsusceptible to petri dish cultivation. They can be successfully cultivated in association with other microbes, meaning in communities of different bacteria species. But without being able to isolate them, research is difficult [13]. Commensal microbiota gradually deteriorates in sick patients. Therefore, research is being conducted to generate new technologies to study the rest of the human microbiome using advances in DNA-sequencing technologies and associated computational methods [14]. Metagenomic sequencing of total fecal DNA samples offers complementary support to classical microbiology, and enables researchers to access previously-inaccessible genomic information from gut bacteria [15,16].

In recent years, a number of functional species and strains have been identified in human metabolic diseases [17]. Gut bacteria can produce various bioactive metabolites which can be detrimental to the host's health, such as those with cytotoxicity, genotoxicity, or immunotoxicity [18], shifting the paradigm of understanding the root cause of the onset and progression of several human metabolic diseases [19].

Gut microbiota modulates the expression of many genes in the human intestinal tract [20], including genes involved in immunity, nutrient absorption, energy metabolism, and intestinal barrier function. It is important to understand genomic diversity of specific members of the gut microbiota if precise nutrition-based approaches are to be realized [21].

In the oral use of live bacteria, there is more research concerning isolated probiotic commercial supplements than there is work concerning health benefits of common fermented foods, since major industries usually do not fund this type of research [22]. Many studies suggest that probiotics may help with diarrhea or symptoms of irritable bowel syndrome, but strong evidence to support their use for most health conditions is lacking in people with sepsis, and probiotics are no panacea [23,24].

Probiotics should not be universally given as a 'one-size-fits-all'; most trials were based on stool samples, which may not really reflect the bacteria living in the gut, as shedding takes place continuously [25]. Besides, taking probiotics after treatment with broad spectrum antibiotics may actually delay the return of normal gut microbiome, a new potential adverse side effect [26].

The One Health concept, introduced at the beginning of the 2000s [27], is a worldwide strategy for promoting multidisciplinary partnerships and information in all facets of health care sciences, perceiving the interrelationship between humans, animals, plants, and their common environment [28]. 
By working with physicians, veterinarians, osteopathic physicians, dentists, pharmacists, nurses, ecologists, wildlife professionals, and other scientific-health and environmentally-related specialists, it will be possible to monitor and control public health threats and learn how diseases spread among people, animals, and the environment [29].

The point of this mini review is to highlight if the requirement for multiconvergence of the research fields of One Health (Human-Animal-Environment), the relationship between microbiota-nutrition and fermented foods, and to underline the idea that future gut-brain research is feasible and achievable (Figure 1).

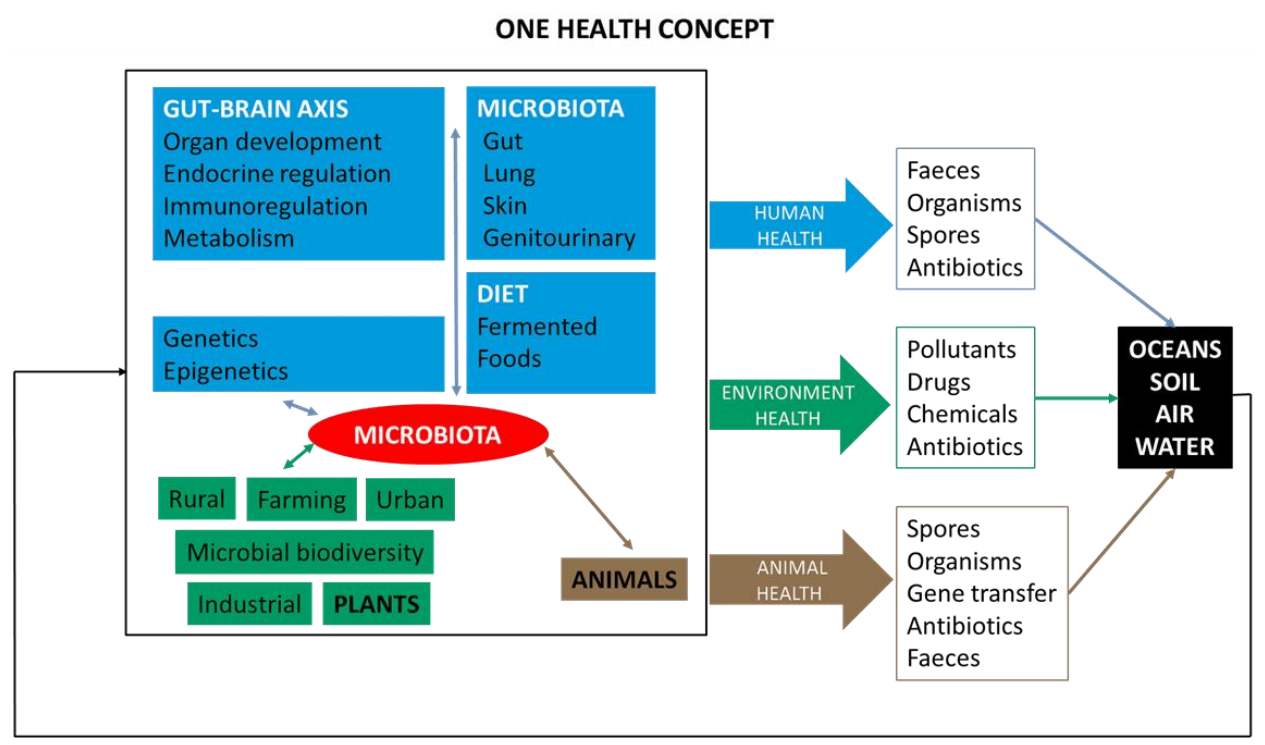

Figure 1. A general picture of the One Health (Human-Animal-Environment) concept as a trans-disciplinary effort. Contribution of the three branches of public health. Microbiota and human metabolic diseases, animal health, and environmental epidemiology.

\section{Microbiota and General Health}

Having an active and natural variety of microorganisms in the gut may improve general health [30]. The good, healthy bacteria make food more digestible through their enzymes, increased vitamin synthesis, and the preservation of nutrients, and also help to reduce sweet cravings, maintain the immune system, and benefit overall gut wellness [31].

The microbiome, consisting of microorganisms and their collective genomes, modulates the host metabolic phenotype, and influences the host immune system. It is now well established that gut bacteria are closely tied to immune health [32]. The gut microbiota regulates L-tryptophan metabolism and identifies the underlying molecular mechanisms of these interactions [33].

A large majority of the immune system resides in the tonsils and gut, so when gut health is imbalanced, it is hard for the body's immune system to function properly [34]. There are also a number of common factors in modern life that can throw human gut bacteria off, such as processed foods and antibiotics. The use of antibiotics does have several short and long-term implications in the ecology of the normal microbiota and gut motility [35].

Research on the health benefits of probiotics is still emerging, mainly from the food and beverage industries and their commercial interests. In contrast, strong, independent scientific evidence to support specific uses of probiotics for most health conditions is still lacking [36].

The administration of probiotics/prebiotics has been shown to alter the composition and functionality of the gut microbiota [37]. Recent evidence indicates that the effects of probiotics are likely to be different from one person to the next [38]. 
In addition, probiotics might be ineffective, and possibly counterproductive, in restoring the baseline gut microbiome after it has been altered by antibiotic treatment. Indeed, probiotics may not be quite as good as was commonly thought, and they could even be harmful if taken after antibiotics [39].

Serious disorders such as obesity, anorexia, irritable bowel syndrome, autism, and posttraumatic stress disorder-which have been thought to be solely psychological—share a common symptom: a hypersensitivity to gut stimuli [40-42].

The role of environmental factors in the development of autism is a crucial and an important area of research concerning how the environment influences and interacts with genetic susceptibility. Factors such as parental age at conception, maternal nutrition, infection during pregnancy, and premature birth are risk factors [43]. Autism (ASD, autism spectrum disorder), a developmental disorder characterized by disturbance in language, perception, and socialization, with no exact known cause, is usually linked with bioenergetic metabolism deficiency [44] and neuro-inflammatory conditions [45], and immune system dysregulation and dreadful gut concerns may improve with better diet and fermented foods (e.g., fermented raw coconut milk) [46,47].

Specific benefits from the direct dietary modulation of the human gut microbiota has been described [48]. Despite the wide array of beneficial mechanisms deployed by probiotic bacteria and fermented foods and beverages, relatively few effects have been supported by clinical data [49].

The interactions (Figure 2) between ingested fermented food and intestinal microbiota, and their correlations to metabolomics profiles and health, represent an important perspective, and independent research on health benefits is still emerging [50,51]. Microbiota is specific to each individual, despite the existence of several bacterial species shared by the majority of adults. A diverse and propitious microbial ecosystem (e.g., Bacteroides fragilis, Bifidobacterium spp. and Faecalibacterium spp.) favors homeostasis, particularly at the level of the disease-immune dialogue [52,53].

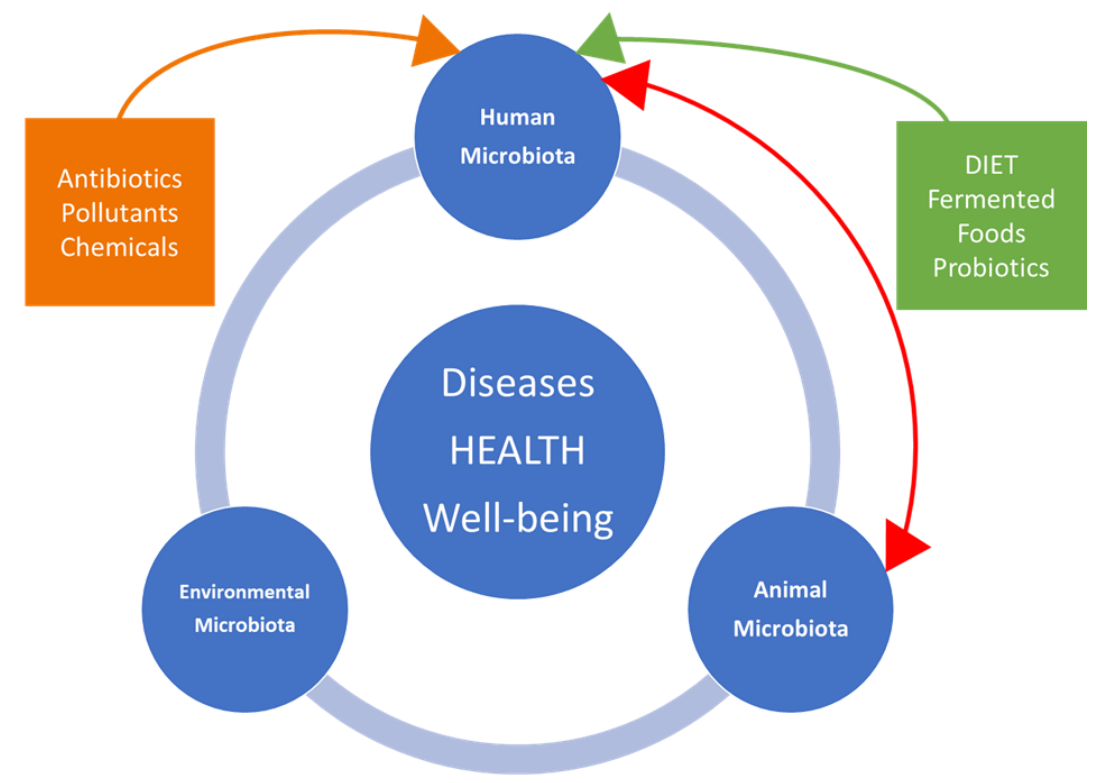

Figure 2. Interactions between dynamics of microbiota in humans, animals, and the associated environment with disease occurrence, salubrity, and well-being.

\section{Fermented Foods, Probiotics, Body and Mind}

The use of fermentation in conserving food and beverage as a means to provide better taste, improve nutrition and food safety, organically preserve foodstuffs, and promote health properties, is a well-known ancient practice. The reasons for fermenting foods and beverages include improvements of a product's storage time, safety, functionality, organoleptic quality, and nutritional quality properties [54]. Not only is this process beneficial for extending shelf-life, but also, fermentation can enhance nutritional properties in a safe and effective manner [55]. 
Many types of food groups, including dairy, vegetables, legumes, cereals, starchy roots, and fruits, as well as meat and fish, can be fermented [56]. Fermented foods and beverages can comprise anywhere from $5-40 \%$ of the human diet in some populations [57].

Phytochemicals, defined as the non-nutritive, naturally-occurring chemicals found in fruits, vegetables, wholegrains, legumes, beans, herbs, spices, nuts, and seeds, are responsible for producing physiological properties, as well as protecting against various environmental stressors of the plant crops. There are more than one thousand known phytochemicals (e.g., lycopene in tomatoes, isoflavones in soy, and flavanoids in fruits). The microbiota comes into contact with a wide variety of dietary components that escape gut digestion and may be affected by phytochemicals [58].

Substantial confusion exists between fermented foods and beverages and the probiotic concept. It is important to address the common misconception that fermented foods are the same thing as probiotics [59]. They are not probiotics, although they may contain them, as their live microbial content is undefined. The term "probiotic" was first coined [60] in 1974, and many authors have described the history and the progress of probiotics and their different applications. Ilya Ilyich Metchnikoff, the Nobel Prize winner in Medicine in 1908, was the first who observed the effect of what is called now "probiotic" [61]. FAO/WHO redefined the term "probiotics", which is now widely accepted as constituting "live microorganisms that, when administered in adequate amounts, confer a health benefit on the host" [62]. Different types of bacteria (e.g., Lactobacillus, Bifidobacterium, Streptococcus, Bacillus) and yeast or mold (e.g., Saccharomyces, Aspergillus, Candida) are used as probiotics. Probably, the first real use of food containing probiotics was fermented milk, but today we have to differentiate between probiotics and probiotic-containing foods (e.g., fermented foods) [63]. The scope and appropriate use of the term "probiotic" has been well clarified (Figure 3) [64].

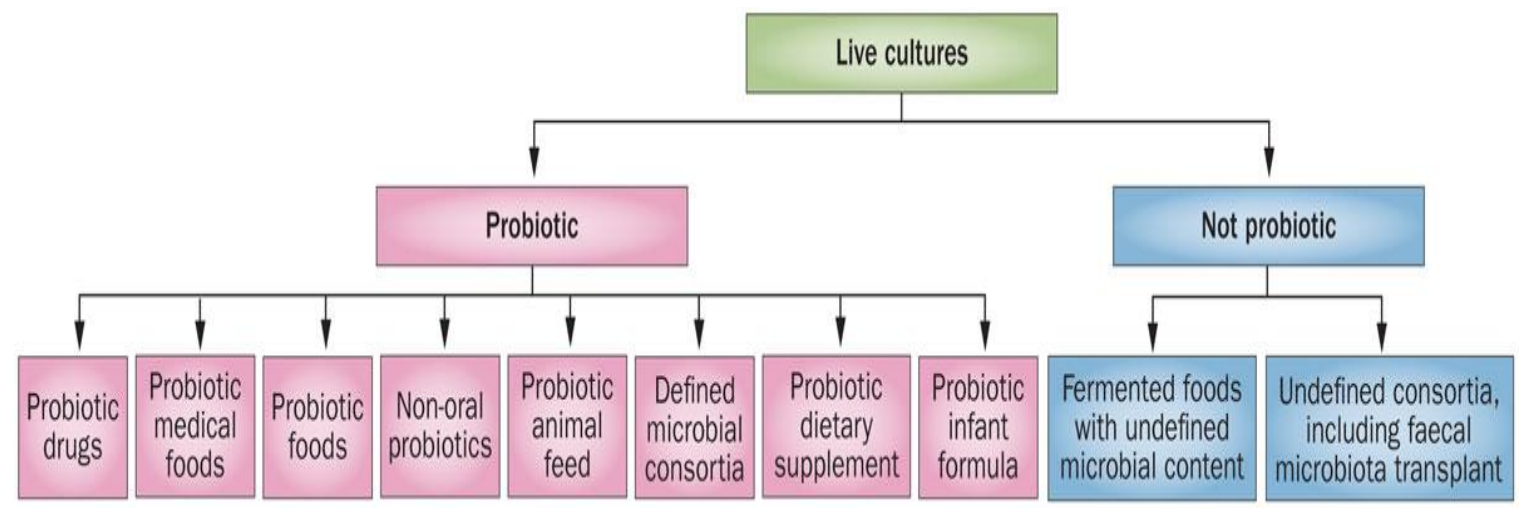

Figure 3. Overall framework for probiotic products [64].

Probiotics are able to renew, restore, and grow affected tissues lining the digestive tract with beneficial microorganisms neutralizing the harmful ones. Useful live microorganisms will regenerate our microflora fermenting our food correctly and improving our health $[65,66]$.

Despite the impact of fermented foods and beverages on gastro-intestinal well-being and diseases, their health benefits or recommended consumption have not been widely translated to global inclusion in world food guidelines [67]. When fermented foods and beverages are supplemented with probiotic bacteria, they provide numerous extra nutritional and health characteristics [68].

Fermented foods and beverages are more popular than ever before, while research into the health benefits of fermented foods is relatively new. Not all fermented foods contain live organisms; beer and wine, for example, undergo steps that remove the organisms, and other fermented foods like bread are heat-treated and the organisms are inactivated. The strain composition and stability of the microbes in fermented foods is not well understood [69].

Fermentation generates adjustments in yeast and live microorganisms cultures in the absence of air, but retains the enzymes, vitamins, and minerals in foods and beverages, which are usually destroyed by processing [70]. The fermenting microorganism, bacteria or yeast, plays a precious role in 
the functional property of fermented foods and beverages [71]. One the biggest benefits of fermented foods comes from the probiotics they might contain [72]. There are currently no authorized European health claims for probiotics, and the application of probiotics is controversial, since the European Food Safety Authority (EFSA) rejected all submitted health claims related to the term "probiotic", while accepting the term "live microorganism cultures" in yoghurt [73].

Traditional and modern dietary practices utilize fermented foods and beverages, contributing significantly to the food chain value and belonging to a category of foods called "functional foods" (e.g., probiotics, prebiotics, stanols and sterols) by having an additional characteristic, i.e., health-promotion or disease prevention effect [74].

Fermentation converts sugars, in the absence of oxygen, into organic acids, gases, alcohols, and carbon dioxide, and provides several benefits such as new and desirable tastes and textures, enhancement of nutrients (e.g., linoleic acid; bioactive peptides), removal of toxic or undesirable food constituents (e.g., phytic acid; bitter-tasting phenolic compounds), delivery of probiotic bacteria (e.g., Lactobacillus delbrueckii subsp. bulgaricus; Streptococcus thermophilus), and inhibition of foodborne pathogens $[75,76]$.

Fermented foods and beverages are useful because they help provide a spectrum of probiotics to foster a vigorous microbiome. Fermented foods with unidentified microbial content cannot be considered probiotic suppliers. The two main effects of the daily consumption of fermented foods are upon the immune system and upon metabolic function [77].

Dealing with fermented foods has parallels with One Health, since it involves the links between human, animal, environment, foods and microbiota that impacts the organoleptic and physicochemical characteristics of foods as well as human health [78].

There are well documented effects of how adverse early life influences on the gut-brain axis and the use of fermented foods and beverages, mainly with probiotic bacteria, can restore a disturbance of the normal luminal habitat, and so change the effects of the central nervous system on the microbiota [79].

Our guts control and deal with every aspect of our health. How we digest our food, and even the food sensitivities we have are linked to our mood, behavior, energy, weight, food cravings, hormone balance, and immunity [80]. The interaction of nutrients with the microbiota is essentially what determines overall health. Eating and drinking fermented foods and beverages, especially organic unpeeled and unpasteurized fruits and vegetables, improves the bioaccessibility and bioavailability of food bioactive components, supplying dietary fibers and essential micronutrients such as trace-elements and phytochemicals, together with enzymes, lactic acid bacteria, and organic acids, all of which are crucial for good health [81].

Changes in the human colonic microbiota fingerprint are associated with the major causes of morbidity and mortality worldwide, diabetes and cardiovascular diseases, due to imbalances between beneficial and pathogenic bacteria [82].

Physiologically-active peptides with different functionalities are produced from food proteins during fermentation and food digestion by lactic acid bacteria. In some fermented products, bioactive peptides (e.g., immunoglobulins, antibacterial peptides, antimicrobial proteins, oligosaccharides, lipids, and other "minor" components) have the potential to be used in the formulation of health-enhancing nutraceuticals [83], and include short amino acid sequences that, upon release from the parent protein, may play different physiological roles, including antioxidant, antihypertensive, antimicrobial, and other bioactivities $[84,85]$.

Fermentation may enhance the benefits of a wide variety of foods, dairy products, herbs, and beverages, acting upon the absorption and activity of their secondary metabolites and chemical elements [86]. However, it is not always possible to clearly distinguish the potential contribution of the microbial content from that of the food matrix. There is recent evidence and consumer perception of the health benefits of fermented foods and beverages [87], beyond the popular recognized effects on the impairment of gastrointestinal function, namely, their relevance on gut microbiota, correlated 
to human health and to several infectious [88], inflammatory, and neoplastic disease processes [89], as well as to brain functionality [90].

Despite disagreement among mental health practitioners and researchers pertaining to the aetiology, categorization, and medical care of several mental disorders [91], current research regarding fermented foods, the microbiome, and their effect on human health, particularly the global epidemic of mental health [92], describes problems associated with the modern lifestyle, and with the western diet being high in sugar and saturated fat [93].

The degradation of the intestinal mucous membrane, weakening the tight barrier against the ingress of harmful substances, and the protection against a reaction to omnipresent harmless compounds, is a primary cause of several disturbances [94].

Ingestion of vibrant probiotics, especially in fermented foods, is found to cause significant positive improvements in balancing intestinal permeability and barrier function [95], with direct effects on metabolic syndrome, atherosclerosis, inflammatory bowel diseases, and colon cancer [96] and indirect effects on depression, anger, anxiety, and levels of stress hormones [97].

Young individuals with autism often have a reduced number of microorganisms in the gut [98], and atypical digestive health conditions may occur, like chronic gastrointestinal and functional bowel disorder, causing discomfort, diarrhea and bloating, abdominal pain and cramping, collectively described as irritable bowel syndrome [99]. Children with autism spectrum, besides having a genetic predisposition, show a disruption of the indigenous gut flora and an elevated number of potentially pathogenic (toxin-producing) Clostridia in the gut $[100,101]$. The effectiveness of fermented foods, mushroom biomass, and probiotics in relieving gut symptoms in autistic children has been studied [102-104].

The involvement of the microbiota in inflammatory diseases may contribute to altered mood via intestinal permeability, systemic and local lipopolysaccharide burden, and even direct-to-brain microbial communication [105]. In future, insights based upon omics techniques will increase our knowledge between pathogens and healthy strains, thereby explaining food ecosystems and their dynamics [106,107].

\section{Fermented Foods in Developing Settings}

Around the world, each culture has its own distinctiveness in terms of food culture and heritage, where fermented foods are included. In the developing world, for people living in poverty, the main priority is not food hygiene, safety, and nutritive factors, as they consume less nutritious foods in which chemical, microbiological, zoonotic, and other hazards may pose a health risk [108].

African traditional fermented foods and beverages have been used since ancient times. Throughout the continent, there is great variety of fermented foods and beverages, mainly sour porridges and drinks. Of the various types of fermentations used to obtain fermented foods and beverages, lactic acid and alcoholic fermentations are the most popular in developing settings, where some $80 \%$ of the population still seek care from traditional healers who prescribe indigenous products.

In Africa, a continent which consumes high levels of lactic acid fermented products, estimates for mental disorders and depression vary widely, but seemingly, such diseases are not less common than in developed societies [109], although factors other than diet exist which may exacerbate conditions such as socio-economic changes, urbanicity, alterations in dietary habits, and, more recently, sedentary behavior among youth [110].

People from Sub-Saharan Africa, often plagued by civil conflicts, drought, floods, famine, and disease, but with huge biodiversity of plants and herbs, tend to rely on traditional healers who often interpret mental illness in terms of possession or curses, and tackle mental health by rituals, but also by recommending traditional plants, herbs, fermented foods, and beverages $[111,112]$. Many rural communities in Africa are totally reliant on traditional fermented foods as the primary source of nutrition for nourishment, as well as for cultural traditional practices [113]. 
In Mozambique and Zimbabwe, traditional fermented foods are used for weaning from the age of four months. The commonest fermented food is known are mahewu, a traditional, fermented, malted, sour, non-alcoholic maize or cassava thin porridge, sour milk and sour porridge [114,115]. The Tanzanian fermented gruel, togwa, has been found to protect against foodborne illnesses in regions that have poor sanitation [116].

However, each person is unique in their needs and sensitivities. Most of us only think of histamine when thinking of allergies. Indigenous fermented foods and beverages, as potential sources of probiotics, may be very therapeutic for some, while others may have an intolerance to histamine since there is no histamine free diet, and this amine, with many functions in the body, occurs naturally, and is a neurotransmitter in the central nervous system [117].

Fruits and vegetables are easily perishable commodities in Africa due to their high water activity and nutritive values. This phenomenon is more critical in tropical and subtropical countries, whose climates favor the growth of spoilage causing microorganisms. It is in developing settings in Africa, Asia [118], and Latin America $[119,120]$ that perhaps the greatest need for probiotics and fermented foods exist; however, for many reasons, this is not the case [121].

\section{One Health Approach and International Organizations}

Antimicrobial resistance is the ability of a microorganism (like bacteria, viruses, and some parasites) to stop an antimicrobial (such as antibiotics, antivirals, and antimalarials) from working against it. As a result, standard treatments become ineffective, infections persist, and may spread to others.

Antibiotic resistance is one of the biggest threats to global health, food security, and development today, and can affect anyone, of any age, in any part of the world. Bacteria, not humans or animals, become antibiotic-resistant; the cause for this is mainly the way antibiotics are prescribed and used without sales supervision and medical or veterinarian control. Tackling antibiotic resistance is a high priority for the United Nations' agencies FAO, and OIE, and the WHO, who are leading multiple initiatives and global action plans.

The United Nations (UN) has become the foremost forum in addressing issues that transcend national boundaries and cannot be resolved by any single country acting alone. While conflict resolution and peacekeeping continue to be among its most visible efforts, the UN, along with its specialized agencies, is also engaged in a wide array of activities to improve people's lives around the world-from disaster relief, through education and advancement of women, to peaceful uses of atomic energy.

Despite great successes since 1953, the UN has, in the past and presently, experienced a number of catastrophic failures, such as the war on sustainable development, global energy goals, refugee and climate change policies, famine, poverty, war conflicts, drugs, diseases, security, terrorism, nuclear proliferation, and human rights issues, and it has suffered disappointing setbacks or complete failures in recent decades.

To improve sanitation and drinking water, the UN organizations FAO and OIE, and the WHO have assumed joint responsibility for addressing zoonotic and other diseases of potentially high socio-economic impact. These international UN organizations developed a Tripartite Concept Note (One Health) setting a course of action and proposing a long term framework for global partnerships which is oriented towards the coordination of global activities addressing health hazards and risks at the human-animal-ecosystems crossroads [122].

The One Health European Joint Program (OHEJP) is a European Commission co-funded scientific collaborative research program intended to help prevent and control food-borne and environmental contaminants that affect human health through joint actions on foodborne zoonoses, antimicrobial resistance, and emerging microbiological hazards [123].

Recognizing the health hazards and risks at the human-animal-ecosystems interface is a key element of their assessments, communication, and management. The One Health approach is 
considered critical for the emergence of antimicrobial drug resistance and on attending prevalent public health concerns, which comprise emerging infectious, parasitic, and zoonotic diseases [124]. Some $60 \%$ of human infectious diseases are of animal origin (zoonoses can be caused by bacteria, fungi, mycobacteria, parasites, viruses, and prions); nearly $75 \%$ of emerging human infectious diseases in the past three decades originated in animal-borne (even aquatic) diseases/pathogens [125]. Some 80\% of such agents can be used for potential bioterrorism and are also pathogens of animal origin [126].

Through strong partnerships with human, animal, environmental health and civil society organizations and professionals, it is considered possible to stimulate advances concerning a safe and secure world with fewer infectious disease threats to human security. But while this UN One Health initiative has proven to be successful from an emerging and infectious disease perspective, its value still needs to be proven in terms of the exchanges and interactions of different microbiomes and elements of microbial communities' transfer among humans, animals, and the environment [127].

\section{One Health, Ecosystems and Veterinary Sciences}

The development of new technologies to perform DNA sequencing has expanded studies on entire microbial communities in humans, animals, and in the environment. The term "microbiota" encompasses the entire complex ecosystem of gut microorganisms, the bulk of which reside mainly in the colon. The terms "microbiome" or the metagenome of the microbiota comprise all of the genetic material within a microbiota.

A complete understanding of human microbiomes in various body mucosa and surfaces requires an evolutionary perspective. The coevolution of humans and microbiota has generated host-specific microbiome structures and gut homeostasis of physiologic, metabolic, and antigenic diversity [128].

Population growth and economic development are leading to rapid changes in our global ecosystems [129]. Health risks are also a result of broader pressure on ecosystems, from the depletion and degradation of freshwater resources to the impacts of global climate change on natural disasters and agricultural production [130]. There is increased connectivity between humans, domestic pets, wildlife, farm animals, and real-world issues such as sanitation, economics, and food security. Ecosystems, landscapes, and a One Health paradigm, including social-ecological holistic approaches become increasingly important $[131,132]$. Such interactions require the integration of health science disciplines that span the spectrum from personalized care to public health [133].

At the national and international levels, these domains are organized in different Ministries, and there is an obstruction by professional corporatism which may impair the implementation of the One Health approach by not pursuing to unify health-related research. Furthermore, overcoming long-standing barriers of privacy and distrust among health professionals and political will are necessary to enable the integration of different health systems [134].

Fermentation, as a human ecological process, begins with the symbiotic human relationship with the microbial habitat [135]. Lifestyle, well-being, and even the survival of humans has been connected to single-celled microorganisms, i.e., fungi (yeasts) and bacteria on fermentation ecosystems [136]. The concept of a whole ecosystem is unpopular, and many have abandoned the idea that ecosystems have boundaries [137].

Gut microbes are extensively purged every one to two days and have the ability to double in number within the space of an hour [138]. In future the ecology of human nutrition may be studied on fermentation ecosystems models [139].

The One Health approach has been criticized for an excessive focus on emerging zoonotic diseases, inadequate incorporation of environmental concepts and expertise, and insufficient incorporation of social science and behavioral aspects of health and governance [140]. Barriers to implementing this strategy include competition over budgets, poor communication, and the need for improved technology [141].

At the national level, it is common to observe Veterinary Medicine, Animal and Veterinary Science, Colleges of Veterinary Medicine, and Veterinary Public Health within the Ministry of Agriculture 
and not in the Ministry of Health; therefore the link between animal health and human health is very precarious. Veterinary medicine is considered an Agrarian profession which does not include the concerns of Health professionals on most criteria, including resources. Environmental health is under the Ministry of Environment, and overall, this partition of responsibilities results in practical difficulties in terms of implementing the collaboration of multiple disciplines and sectors working locally, nationally, and globally to attain optimal health for people, animals, and the environment.

At the international level, agencies such as The European Centre for Disease Prevention and Control (ECDC), The European Food Safety Authority (EFSA), the forum One Health European Joint Programme (OHEJP), and others, follow the developments on zoonoses with the mission of identifying, assessing and communicating current and emerging threats to human health posed by these diseases, as well as zoonotic agents, antimicrobial resistance, and food-borne outbreaks. However, the monitoring and surveillance schemes of most zoonotic agents are not harmonized between Member States, adding to existing complexity.

\section{Concluding Remarks}

Fermented food microbiology is an excellent model that is deeply connected to the dynamics that shape the human microbiota in different body sites. Perceiving microbial community interactions, essential for the threat of global antimicrobial resistance, will help to reveal, via a holistic approach, the unknown secrets of the human microbiome and the interactions which greatly influence multiple forms of human health, nutrition, well-being.

The relevance and potential of fermented foods and beverages, with contrasting and inconclusive results, and advocacy for their inclusion into dietary guidelines, depend on future clinical research. The limitations and inconsistencies in the current body of evidence mean that, presently, no definitive conclusions can be drawn on the potential health benefits of fermented products.

It is not easy to apply trans-inter-multi-disciplinary research required by the One Health approach due to its complexity, but the associated human-animal-environmental microbiota and health threats and risks demand that many challenges and handicaps must be overcome. After two decades, One Health still needs to prove its use and its ability to be applicable in parallel with the present bold reforms which are underway among major United Nations departments in order to more effectively respond to global crises, streamline activities, increase accountability, and ensure effectiveness.

Author Contributions: V.B. \& T.F. reviewed the literature and drafted the manuscript. J.F., L.P., M.P. read and revised the manuscript. T.F. responsible for the concept and preparation of final article.

Funding: This research received no external funding.

Conflicts of Interest: The authors declare no conflicts of interest.

\section{References}

1. Han, H.; Li, Y.; Fang, J.; Liu, G.; Yin, J.; Li, T.; Yin, Y. Gut Microbiota and Type 1 Diabetes. Int. J. Mol. Sci. 2018, 19, 995. [CrossRef] [PubMed]

2. Kostic, A.D.; Michael, R.; Howitt, M.R.; Garrett, W.S. Exploring host-microbiota interactions in animal models and humans. Genes Dev. 2013, 27, 701-718. [CrossRef] [PubMed]

3. Aagaard, K.; Ma, J.; Antony, K.M.; Ganu, R.; Petrosino, J.; Versalovic, J. The Placenta Harbors a Unique Microbiome. Sci. Transl. Med. 2014, 6, 237ra65. [CrossRef] [PubMed]

4. Walker, R.W.; Clemente, J.C.; Peter, I.; Loos, R.J.F. The prenatal gut microbiome: Are we colonized with bacteria in utero? Pediatr. Obes. 2017, 12 (Suppl. 1), 3-17. [CrossRef] [PubMed]

5. Dzidic, M.; Boix-Amorós, A.; Selma-Royo, M.; Mira, A.; Collado, M.C. Gut Microbiota and Mucosal Immunity in the Neonate. Med. Sci. 2018, 6, 56. [CrossRef] [PubMed]

6. Perez-Muñoz, M.E.; Arrieta, M.-C.; Ramer-Tait, A.E.; Walter, J. A critical assessment of the "sterile womb" and "in utero colonization" hypotheses: Implications for research on the pioneer infant microbiome. Microbiome 2017, 5, 48. [CrossRef] [PubMed]

7. O'Hara, A.M.; Shanahan, F. The gut flora as a forgotten organ. EMBO Rep. 2006, 7, 688-693. [CrossRef] 
8. Cenit, M.C.; Sanz, Y.; Codoñer-Franch, P. Influence of gut microbiota on neuropsychiatric disorders. World J. Gastroenterol. 2017, 23, 5486-5498. [CrossRef]

9. Lira-Junior, R.; Boström, E.A. Oral-gut connection: One step closer to an integrated view of the gastrointestinal tract? Mucosal Immunol. 2018, 11, 316-318. [CrossRef]

10. Wampach, L.; Heintz-Buschart, A.; Hogan, A.; Muller, E.E.; Narayanasamy, S.; Laczny, C.C.; Hugerth, L.W.; Bindl, L.; Bottu, J.; Andersson, A.F.; et al. Colonization and succession within the human gut microbiome by archaea, bacteria, and microeukaryotes during the first year of life. Front. Microbiol. 2017, 8, 738. [CrossRef]

11. Sender, R.; Fuchs, S.; Milo, R. Revised Estimates for the Number of Human and Bacteria Cells in the Body. PLoS Biol. 2016, 14, e1002533. [CrossRef] [PubMed]

12. Belizário, J.E.; Napolitano, M. Human microbiomes and their roles in dysbiosis, common diseases, and novel therapeutic approaches. Front. Microbiol. 2015, 6, 1050. [CrossRef] [PubMed]

13. Vemuri, R.; Gundamaraju, R.; Shastri, M.D.; Shukla, S.D.; Kalpurath, K.; Ball, M.; Tristram, S.; Shankar, E.M.; Ahuja, K.; Eri, R. Gut Microbial Changes, Interactions, and Their Implications on Human Lifecycle: An Ageing Perspective. Biomed. Res Int. 2018, 2018, 4178607. [CrossRef] [PubMed]

14. Thursby, E.; Juge, N. Introduction to the human gut microbiota. Biochem. J. 2017, 474, 1823-1836. [CrossRef] [PubMed]

15. Schloss, P.D.; Handelsman, J. Metagenomics for studying unculturable microorganisms: Cutting the Gordian knot. Genome Biol. 2005, 6, 229. [CrossRef] [PubMed]

16. Guirro, M.; Costa, A.; Gual-Grau, A.; Mayneris-Perxachs, J.; Torrell, H.; Herrero, P.; Canela, N.; Arola, L. Multi-omics approach to elucidate the gut microbiota activity: Metaproteomics and metagenomics connection. Electrophoresis 2018, 39, 1692-1701. [CrossRef] [PubMed]

17. Zhang, C.; Zhao, L. Strain-level dissection of the contribution of the gut microbiome to human metabolic disease. Genome Med. 2016, 8, 41. [CrossRef]

18. Butel, M.J.; Waligora-Dupriet, A.J.; Wydau-Dematteis, S. The developing gut microbiota and its consequences for health. J. Dev. Orig. Health Dis. 2018, 1-8. [CrossRef]

19. Wu, G.; Zhang, C.; Wu, H.; Wang, R.; Shen, J.; Wang, L.; Zhao, Y.; Pang, X.; Zhang, X.; Zhao, L.; et al. Genomic microdiversity of Bifidobacterium pseudocatenulatum underlying differential strain-level responses to dietary carbohydrate intervention. MBio 2017, 8, e2348-16. [CrossRef]

20. Dahiya, D.K.; Renuka; Puniya, M.; Shandilya, U.K.; Dhewa, T.; Kumar, N.; Kumar, S.; Puniya, A.K.; Shukla, P. Gut Microbiota Modulation and Its Relationship with Obesity Using Prebiotic Fibers and Probiotics: A Review. Front. Microbiol. 2017, 8, 563. [CrossRef]

21. Gagliardi, A.; Totino, V.; Cacciotti, F.; Iebba, V.; Neroni, B.; Bonfiglio, V.; Trancassini, M.; Passariello, C.; Pantanella, F.; Schippa, S. Rebuilding of the gut ecosystem. Int. J. Environ. Res. Public Health 2018, 15, 1679. [CrossRef] [PubMed]

22. Cicerone, C.; Nenna, R.; Pontone, S. Th17, intestinal microbiota and the abnormal immune response in the pathogenesis of celiac disease. Gastroenterol. Hepatol. Bed Bench 2015, 8, 117-122. [PubMed]

23. Hemarajata, P.; Versalovic, J. Effects of probiotics on gut microbiota: Mechanisms of intestinal immunomodulation and neuromodulation. Therap. Adv. Gastroenterol. 2013, 6, 39-51. [CrossRef] [PubMed]

24. Shimizu, K.; Yamada, T.; Ogura, H.; Mohri, T.; Kiguchi, T.; Fujimi, S.; Asahara, T.; Yamada, T.; Ojima, M.; Ikeda, M.; et al. Synbiotics modulate gut microbiota and reduce enteritis and ventilator-associated pneumonia in patients with sepsis: A randomized controlled trial. Crit. Care 2018, 22, 239. [CrossRef] [PubMed]

25. Zuo, T.; Ng, S.C. The Gut Microbiota in the Pathogenesis and Therapeutics of Inflammatory Bowel Disease. Front. Microbiol. 2018, 9, 2247. [CrossRef] [PubMed]

26. Zmora, N.; Zilberman-Schapira, G.; Suez, J.; Mor, U.; Dori-Bachash, M.; Bashiardes, S.; Kotler, E.; Zur, M.; Regev-Lehavi, D.; Brik, R.B.; et al. Personalized Gut Mucosal Colonization Resistance to Empiric Probiotics Is Associated with Unique Host and Microbiome Features. Cell 2018, 174, 1388-1405. [CrossRef] [PubMed]

27. Gibbs, E.P.J. The evolution of One Health: A decade of progress and challenges for the future. Vet. Rec. 2014, 174, 85-91. [CrossRef]

28. FAO/OIE/WHO. WHO Global Principles for the Containment of Antimicrobial Resistance in Animals Intended for Food 2000; WHO: Geneva, Switzerland, 2000.

29. Stadtländer, C.T.K.-H. One Health: People, animals, and the environment. Infect. Ecol. Epidemiol. 2015, 5, 30514. [CrossRef] 
30. Janakiraman, M.; Krishnamoorthy, G. Emerging Role of Diet and Microbiota Interactions in Neuroinflammation. Front. Immunol. 2018, 9, 2067. [CrossRef]

31. Hashemi, Z.; Fouhse, J.; Im, H.S.; Chan, C.B.; Willing, B.P. Dietary pea fiber supplementation improves glycemia and induces changes in the composition of gut microbiota, serum short-chain fatty acid profile and expression of mucins in glucose intolerant rats. Nutrients 2017, 9, 1236. [CrossRef]

32. Rubio, C.; Schmidt, P.T. Severe Defects in the Macrophage Barrier to Gut Microflora in Inflammatory Bowel Disease and Colon Cancer. Anticancer Res. 2018, 38, 3811-3815. [CrossRef] [PubMed]

33. Gao, J.; Xu, K.; Liu, G.; Liu, G.; Bai, M.; Peng, C.; Li, T.; Yin, Y. Impact of the Gut Microbiota on Intestinal Immunity Mediated by Tryptophan Metabolism. Front. Cell. Infect. Microbiol. 2018, 8, 13. [CrossRef] [PubMed]

34. Opazo, M.C.; Ortega-Rocha, E.M.; Coronado-Arrázola, I.; Bonifaz, L.C.; Boudin, H.; Neunlist, M.; Bueno, S.M.; Kalergis, A.M.; Riedel, C.A. Intestinal Microbiota Influences Non-intestinal Related Autoimmune Diseases. Front. Microbiol. 2018, 9, 432. [CrossRef] [PubMed]

35. Jandhyala, S.M.; Talukdar, R.; Subramanyam, C.; Vuyyuru, H.; Sasikala, M.; Reddy, D.N. Role of the normal gut microbiota. World J. Gastroenterol. 2015, 21, 8787-8803. [CrossRef] [PubMed]

36. Suez, J.; Zmora, N.; Zilberman-Schapira, G.; Mor, U.; Dori-Bachash, M.; Bashiardes, S.; Zur, M.; Regev-Lehavi, D.; Ben-Zeev Brik, R.; Federici, S.; et al. Post-Antibiotic Gut Mucosal Microbiome Reconstitution Is Impaired by Probiotics and Improved by Autologous FMT. Cell 2018, 174, 1406-1423. [CrossRef]

37. Severyn, C.J.; Bhatt, A.S. With probiotics, resistance is not always futile. Cell Host Microbe 2018, $24,334$. [CrossRef] [PubMed]

38. Parker, E.A.; Roy, T.; D'Adamo, C.R.; Wieland, L.S. Probiotics and gastrointestinal conditions: An overview of evidence from the Cochrane Collaboration. Nutrition 2018, 45, 125-134. [CrossRef]

39. Azad, M.A.K.; Sarker, M.; Li, T.; Yin, J. Probiotic Species in the Modulation of Gut Microbiota: An Overview. Biomed. Res. Int. 2018, 9478630. [CrossRef]

40. Fadgyas-Stanculete, M.; Buga, A.-M.; Popa-Wagner, A.; Dumitrascu, D.L. The relationship between irritable bowel syndrome and psychiatric disorders: From molecular changes to clinical manifestations. J. Mol. Psychiatry 2014, 2, 4. [CrossRef]

41. Lee, P.; Yacyshyn, B.R.; Yacyshyn, M. Gut microbiota and obesity: An opportunity to alter obesity through Fecal Microbiota Transplant (FMT). Diabetes Obes. Metab. 2018. [CrossRef]

42. Karimi, P.; Kamali, E.; Mousavi, S.M.; Karahmadi, M. Environmental factors influencing the risk of autism. J. Res. Med. Sci. 2017, 22, 27. [CrossRef] [PubMed]

43. Gérard, P. Gut microbiota and obesity. Cell Mol. Life Sci. 2016, 73, 147-162. [CrossRef] [PubMed]

44. Delhey, L.; Kilinc, E.N.; Yin, L.; Slattery, J.; Tippett, M.; Wynne, R.; Rose, S.; Kahler, S.; Damle, S.; Legido, A.; et al. Bioenergetic variation is related to autism symptomatology. Metab. Brain Dis. 2017, 32, 2021-2031. [CrossRef] [PubMed]

45. Freedman, S.N.; Shahi, S.K.; Mangalam, A.K. The "Gut Feeling": Breaking Down the Role of Gut Microbiome in Multiple Sclerosis. Neurotherapeutics 2018, 15, 109-125. [CrossRef] [PubMed]

46. Adams, J.B.; Audhya, T.; Geis, E.; Gehn, E.; Fimbres, V.; Pollard, E.L.; Mitchell, J.; Ingram, J.; Hellmers, R.; Laake, D.; et al. Comprehensive Nutritional and Dietary Intervention for Autism Spectrum Disorder-A Randomized, Controlled 12-Month Trial. Nutrients 2018, 10, 369. [CrossRef] [PubMed]

47. Hughes, H.K.; Rose, D.; Ashwood, P. The Gut Microbiota and Dysbiosis in Autism Spectrum Disorders. Curr. Neurol. Neurosci. Rep. 2018, 18, 81. [CrossRef] [PubMed]

48. Mohajeri, M.H.; Brummer, R.J.M.; Rastall, R.A.; Weersma, R.K.; Harmsen, H.J.M.; Faas, M.; Eggersdorfer, M. The role of the microbiome for human health: From basic science to clinical applications. Eur. J. Nutr. 2018, 57 (Suppl. 1), 1-4. [CrossRef]

49. Goldenberg, R.L.; Hauth, J.C.; Andrews, W.W. Intrauterine infection and preterm delivery. N. Engl. J. Med. 2000, 342, 1500-1507. [CrossRef]

50. Sánchez, B.; Delgado, S.; Blanco-Míguez, A.; Lourenço, A.; Gueimonde, M.; Margolles, A. Probiotics, gut microbiota, and their influence on host health and disease. Mol. Nutr. Food Res. 2017, 61. [CrossRef]

51. Singh, R.K.; Chang, H.W.; Yan, D.; Lee, K.M.; Ucmak, D.; Wong, K.; Abrouk, M.; Farahnik, B.; Nakamura, M.; Zhu, T.H.; et al. Influence of diet on the gut microbiome and implications for human health. J. Transl. Med. 2017, 15, 73. [CrossRef] 
52. Howarth, G.S.; Wang, H. Role of endogenous microbiota, probiotics and their biological products in human health. Nutrients 2013, 5, 58-81. [CrossRef] [PubMed]

53. González-Sarrías, A.; Romo-Vaquero, M.; García-Villalba, R.; Cortés-Martín, A.; Selma, M.V.; Espín, J.C. The Endotoxemia Marker Lipopolysaccharide-Binding Protein is Reduced in Overweight-Obese Subjects Consuming Pomegranate Extract by Modulating the Gut Microbiota: A Randomized Clinical Trial. Mol. Nutr. Food Res. 2018, 62, 11. [CrossRef] [PubMed]

54. Hutkins, R.W. Microbiology and Technology of Fermented Foods, 2nd ed.; Hoboken, N.J., Ed.; Wiley-Blackwell: Hoboken, NJ, USA, September 2018; p. 616.

55. Fridman, W.H.; Zitvogel, L.; Sautes-Fridman, C.; Kroemer, G. The immune contexture in cancer prognosis and treatment. Nat. Rev. Clin. Oncol. 2017, 14, 717-734. [CrossRef] [PubMed]

56. Iwu, M.M. Food as Medicine: Functional Food Plants of Africa. Series: Functional Foods and Nutraceuticals, 1st ed.; CRC Press: Boca Raton, FL, USA, 2016.

57. Borresen, E.C.; Henderson, A.J.; Kumar, A.; Weir, T.L.; Ryan, E.P. Fermented foods: Patented approaches and formulations for nutritional supplementation and health promotion. Recent Pat. Food Nutr. Agric. 2012, 4, 134-140. [CrossRef] [PubMed]

58. Carrera-Quintanar, L.; Roa, R.I.L.; Quintero-Fabián, S.; Sánchez-Sánchez, M.A.; Vizmanos BOrtuño-Sahagún, D. Phytochemicals That Influence Gut Microbiota as Prophylactics and for the Treatment of Obesity and Inflammatory Diseases. Mediat. Inflamm. 2018, 2018, 9734845. [CrossRef]

59. Gibson, G.; Hutkins, R.; Sanders, M.E.; Prescott, S.L.; Reimer, R.A.; Salminen, S.J.; Scott, K.; Stanton, C.; Swanson, K.S.; Cani, P.D.; et al. Expert consensus document: The International Scientific Association for Probiotics and Prebiotics (ISAPP) consensus statement on the definition and scope of prebiotics. Nat. Rev. Gastroenterol. Hepatol. 2017, 14, 491-502. [CrossRef] [PubMed]

60. Parker, R.B. Probiotics, the other half of the antibiotic story. Anim. Nutr. Health. 1974, 29, 4-8.

61. Metchnikoff, I.I. The Prolongation of Life: Optimistic Studies; Springer Publishing Company: New York, NY, USA, 2004.

62. Reid, G. Probiotics: Definition, scope and mechanisms of action. Best Pract. Res. Clin. Gastroenterol. 2016, 30, 17-25. [CrossRef]

63. Gismondo, M.R.; Drago, L.; Lombardi, A. Review of Probiotics available to modify gastrointestinal flora. Int. J. Antimicrob. Agents 1999, 12, 287-292. [CrossRef]

64. Hill, C.; Guarner, F.; Reid, G.; Gibson, G.R.; Merenstein, D.J.; Pot, B.; Morelli, L.; Canani, R.B.; Flint, H.J.; Salminen, S.; et al. The International Scientific Association for Probiotics and Prebiotics consensus statement on the scope and appropriate use of the term probiotic. Nat. Rev. Gastroenterol. Hepatol. 2014, 11, 506-514. [CrossRef]

65. Reid, G.; Sanders, M.E.; Gaskins, H.R.; Gibson, G.R.; Mercenier, A.; Rastall, R.; Roberfroid, M.; Rowland, I.; Cherbut, C.; Klaenhammer, T.R. New scientific paradigms for Probiotics and prebiotics. J. Clin. Gastroenterol. 2003, 37, 105-118. [CrossRef] [PubMed]

66. Brusaferro, A.; Cavalli, E.; Farinelli, E.; Cozzali, R.; Principi, N.; Esposito, S. Gut dysbiosis and paediatric crohn's disease. J. Infect. 2018. [CrossRef] [PubMed]

67. Bell, V.; Ferrão, J.; Fernandes, T. Nutritional Guidelines and Fermented Food Frameworks. Foods 2017, 6, 65. [CrossRef]

68. Gille, D.; Schmid, A.; Walther, B.; Vergères, G. Fermented Food and Non-Communicable Chronic Diseases: A Review. Nutrients 2018, 10, 448. [CrossRef] [PubMed]

69. Marco, M.L.; Heeney, D.; Binda, S.; Cifelli, C.J.; Cotter, P.D.; Foligné, B.; Gänzle, M.; Kort, R.; Pasin, G.; Pihlanto, A.; et al. Health benefits of fermented foods: Microbiota and beyond. Curr. Opin. Biotechnol. 2017, 44, 94-102. [CrossRef] [PubMed]

70. Hoffmann, D.E.; Fraser, C.M.; Palumbo, F.B.; Ravel, J.; Rothenberg, K.; Rowthorn, V.; Schwartz, J. Science and regulation. Probiotics: Finding the right regulatory balance. Science 2013, 342, 314-315. [CrossRef] [PubMed]

71. Amit, S.K.; Uddin, M.; Rahman, R.; Islam, R.; Khan, M.S. A review on mechanisms and commercial aspects of food preservation and processing. Agric. Food Secur. 2017, 6, 51. [CrossRef]

72. Sivamaruthi, B.S.; Kesika, P.; Chaiyasut, C. Impact of Fermented Foods on Human Cognitive Function-A Review of Outcome of Clinical Trials. Sci. Pharm. 2018, 86, 22. [CrossRef] 
73. European Food Safety Authority (EFSA) Panel on Dietetic Products, Nutrition and Allergies. Scientific Opinion on the substantiation of health claims related to live yoghurt cultures and improved lactose digestion (ID 1143, 2976) pursuant to Article 13(1) of Regulation (EC) No 1924/2006. EFSA J. 2010, 8, 1763.

74. British Nutrition Foundation. Available online: https://www.nutrition.org.uk/nutritionscience/foodfacts/ functional-foods.html (accessed on 11 October 2018).

75. Hu, S.; Cao, X.; Wu, Y.; Mei, X.; Xu, H.; Wang, Y.; Zhang, X.; Gong, L.; Li, W. Effects of Probiotic Bacillus as an Alternative of Antibiotics on Digestive Enzymes Activity and Intestinal Integrity of Piglets. Front. Microbiol. 2018, 9, 2427. [CrossRef]

76. Laurent-Babot, C.; Guyot, J.P. Should Research on the Nutritional Potential and Health Benefits of Fermented Cereals Focus More on the General Health Status of Populations in Developing Countries? Microorganisms 2017, 5, 40. [CrossRef] [PubMed]

77. Rezac, S.; Kok, C.R.; Heermann, M.; Hutkins, R. Fermented Foods as a Dietary Source of Live Organisms. Front. Microbiol. 2018, 9, 1785. [CrossRef] [PubMed]

78. Behravesh, C.B. One Health: People, Animals, and the Environment. Emerg. Infect. Dis. 2016, 22, 766-767. [CrossRef]

79. Kim, N.; Yun, M.; Oh, Y.J.; Choi, H.J. Mind-altering with the gut: Modulation of the gut-brain axis with probiotics. J. Microbiol. 2018, 56, 172-182. [CrossRef] [PubMed]

80. Dicks, L.M.; Dreyer, L.; Smith, C.; Van Staden, A.D. A Review: The Fate of Bacteriocins in the Human Gastro-Intestinal Tract: Do They Cross the Gut-Blood Barrier? Front. Microbiol. 2018, 9, 2297. [CrossRef] [PubMed]

81. Ferrão, J.; Bell, V.; Calabrese, V.; Pimentel, L.; Pintado, M.; Fernandes, T.H. Impact of Mushroom Nutrition on Microbiota and Potential for Preventative Health. J. Food Nutr. Res. 2017, 5, 226-233. [CrossRef]

82. Vamanu, E.; Pelinescu, D.; Sarbu, I. Comparative Fingerprinting of the Human Microbiota in Diabetes and Cardiovascular Disease. J. Med. Food 2016, 19, 1188-1195. [CrossRef]

83. Gianfranceschi, G.L.; Gianfranceschi, G.; Quassinti, L.; Bramucci, M. Biochemical requirements of bioactive peptides for nutraceutical efficacy. J. Funct. Foods 2018, 47, 252-263. [CrossRef]

84. Park, Y.W.; Nam, M.S. Bioactive Peptides in Milk and Dairy Products: A Review. Korean J. Food Sci. Anim. Resour. 2015, 35, 831-840. [CrossRef]

85. Hayes, M.; García-Vaquero, M. Bioactive Compounds from Fermented Food Products. In Novel Food Fermentation Technologies; Ojha, K., Tiwari, B., Eds.; Food Engineering Series; Springer: Cham, Switzerland, 2016.

86. Penna, M.; Gębski, J.; Gutkowska, K.; Żakowska-Biemans, S. Importance of Health Aspects in Polish Consumer Choices of Dairy Products. Nutrients 2018, 10, 1007. [CrossRef]

87. Annunziata, A.; Mariani, A. Consumer Perception of Sustainability Attributes in Organic and Local Food. Recent Pat. Food Nutr. Agric. 2018, 9, 87-96. [CrossRef]

88. Cryan, J.F.; O'Mahony, S.M. The microbiome-gut-brain axis: From bowel to behavior. Neurogastroenterol. Motil. 2011, 23, 187-192. [CrossRef] [PubMed]

89. Browne, H.P.; Neville, B.A.; Forster, S.C.; Lawley, T.D. Transmission of the gut microbiota: Spreading of health. Nat. Rev. Microbiol. 2017, 15, 531-543. [CrossRef] [PubMed]

90. Navarro, F.; Liu, Y.; Rhoads, J.M. Can probiotics benefit children with autism spectrum disorders? World J. Gastroenterol. 2016, 22, 10093-10102. [CrossRef] [PubMed]

91. Gilbert, J.A.; Krajmalnik-Brown, R.; Porazinska, D.L.; Weiss, S.J.; Knight, R. Toward Effective Probiotics for Autism and Other Neurodevelopmental Disorders. Cell 2013, 155, 1446-1448. [CrossRef] [PubMed]

92. Liang, S.; Wu, X.; Jin, F. Gut-Brain Psychology: Rethinking Psychology from the Microbiota-Gut-Brain Axis. Front. Integr. Neurosci. 2018, 12, 33. [CrossRef] [PubMed]

93. Yang, Y.; Tian, J.; Yang, B. Targeting gut microbiome: A novel and potential therapy for autism. Life Sci. 2018, 194, 111-119. [CrossRef]

94. Genser, L.; Aguanno, D.; Soula, H.A.; Dong, L.; Trystram, L.; Assmann, K.; Salem, J.-E.; Vaillant, J.-C.; Oppert, J.M.; Laugerette, F.; et al. Increased jejunal permeability in human obesity is revealed by a lipid challenge and is linked to inflammation and type 2 diabetes: Jejunal permeability in human obesity. J. Pathol. 2018, 246. [CrossRef] 
95. Hiippala, K.; Jouhten, H.; Ronk ainen, A.; Hartikainen, A.; Kailunanen, V.; Jalanka, J.; Satokari, R. The potential of gut commensals in reinforcing intestinal barrier function and alleviating inflammation. Nutrients 2018, 10, 988. [CrossRef]

96. Wang, L.W.; Tancredi, D.J.; Thomas, D.W. The prevalence of gastrointestinal problems in children across the United States with autism spectrum disorders from families with multiple affected members. J. Dev. Behav. Pediatr. 2011, 32, 351-360. [CrossRef]

97. Heidari, F.; Abbaszadeh, S.; Mirak, S.E.M. Evaluation Effect of Combination Probiotics and Antibiotics in the Prevention of Recurrent Urinary Tract Infection (UTI) in Women. Biomed. Pharmacol. J. 2017, 10, 691-698. [CrossRef]

98. Duca, F.; Gérard, P.; Covasa, M.; Lepage, P. Metabolic interplay between gut bacteria and their host. Front. Horm. Res. 2014, 42, 73-82. [CrossRef]

99. Strati, F.; Cavalieri, D.; Albanese, D.; De Felice, C.; Donati, C.; Hayek, J.; Jousson, O.; Leoncini, S.; Renzi, D.; Calabrò, A.; et al. New evidences on the altered gut microbiota in autism spectrum disorders. Microbiome 2017, 5, 24. [CrossRef] [PubMed]

100. Moschen, A.R.; Wieser, V.; Tilg, H. Dietary factors: Major regulators of the gut's microbiota. Gut Liver 2012, 6, 411-416. [CrossRef] [PubMed]

101. Piwowarczyk, A.; Horvath, A.; Łukasik, J.; Pisula, E.; Szajewska, H. Gluten- and casein-free diet and autism spectrum disorders in children: A systematic review. Eur. J. Nutr. 2018, 57, 433-440. [CrossRef] [PubMed]

102. Kho, Z.Y.; Lal, S.K. The Human Gut Microbiome-A Potential Controller of Wellness and Disease. Front. Microbiol. 2018, 9, 1835. [CrossRef] [PubMed]

103. Miller, A.H.; Raison, C.L. The role of inflammation in depression: From evolutionary imperative to modern treatment target. Nat. Rev. Immunol. 2015, 16, 22-34. [CrossRef]

104. Vuong, H.E.; Hsiao, E.Y. Emerging Roles for the Gut Microbiome in Autism Spectrum Disorder. Rev. Art. Biol. Psychiatry 2017, 81, 411-423. [CrossRef]

105. Berding, K.; Donovan, S.M. Microbiome and nutrition in autism spectrum disorder: Current knowledge and research needs. Nutr. Rev. 2016, 74, 723-736. [CrossRef]

106. Den Besten, H.M.W.; Amézquita, A.; Bover-Cid, S.; Dagnas, S.; Ellouze, M.; Guillou, S.; Nychas, G.; O’Mahony, C.; Pérez-Rodriguez, F.; Membré, J.-M. Next generation of microbiological risk assessment: Potential of omics data for exposure assessment. Int. J. Food Microbiol. 2018, 287, 18-27. [CrossRef]

107. Sirangelo, T.M. Human Gut Microbiome Analysis and Multi-omics Approach. Int. J. Pharma Med. Biol. Sci. 2018, 7, 52-57.

108. He, M.; Shi, B. Gut microbiota as a potential target of metabolic syndrome: The role of probiotics and prebiotics. Cell Biosci. 2017, 7, 54. [CrossRef] [PubMed]

109. Willson, K.; Situ, C. Systematic Review on Effects of Diet on Gut Microbiota in Relation to Metabolic Syndromes. J. Clin. Nutr. Metab. 2017, 1, 2.

110. Routy, B.; Gopalakrishnan, V.; Daillère, R.; Zitvogel, L.; Wargo, J.A.; Kroemer, G. The gut microbiota influences anticancer immunosurveillance and general health. Nat. Rev. Clin. Oncol. 2018, 15, 382-396. [CrossRef] [PubMed]

111. Asare, M.; Danquah, S.A. The relationship between physical activity, sedentary behaviour and mental health in Ghanaian adolescents. Child Adol. Psychiatry Ment. Health 2015, 9, 11. [CrossRef] [PubMed]

112. Mahomoodally, M.F. Traditional Medicines in Africa: An Appraisal of Ten Potent African Medicinal Plants. Evid. Based Complement. Altern. Med. 2013, 14, 617459. [CrossRef] [PubMed]

113. Anukam, K.C.; Reid, G. African traditional fermented foods and probiotics. J. Med. Food 2009, 12, 1177-1184. [CrossRef]

114. Duthé, G.; Rossier, C.; Bonnet, D.; Soura, A.B.; Corker, J. Mental health and urban living in sub-Saharan Africa: Major depressive episodes among the urban poor in Ouagadougou, Burkina Faso. Popul. Health Metr. 2016, 14, 18. [CrossRef]

115. Simango, C. Potential use of traditional fermented foods for weaning in Zimbabwe. Soc. Sci. Med. 1997, 44, 1065-1068. [CrossRef]

116. Mugula, J.K.; Sørhaug, T.; Stepaniak, L. Proteolytic activities in togwa, a Tanzanian fermented food. Int. J. Food Microbiol. 2003, 84, 1-12. [CrossRef]

117. Kohn, J.B. Is there a diet for histamine intolerance? J. Acad. Nutr. Diet. 2014, 114, 1860. [CrossRef] [PubMed] 
118. Swain, M.R.; Anandharaj, M.; Ray, R.C.; Parveen Rani, R. Fermented fruits and vegetables of Asia: A potential source of probiotics. Biotechnol. Res. Int. 2014, 2014, 250424. [CrossRef] [PubMed]

119. Penna, A.L.B.; Nero, L.A.; Todorov, S.D. Fermented Foods of Latin America: From Traditional Knowledge to Innovative Applications. In Food Biology Series; CRC Press: Boca Raton, FL, USA, 2017; p. 338, ISBN 9781498738118.

120. Ramos, C.L.; Schwan, R.F. Technological and nutritional aspects of indigenous Latin America fermented foods. Curr. Opin. Food Sci. 2017, 13, 97-102. [CrossRef]

121. Franz, C.M.A.P.; Huch, M.; Mathara, J.M.; Abriouel, H.; Benomar, N.; Reid, G.; Galvez, A.; Holzapfel, W.H. African fermented foods and probiotics. Int. J. Food Microbiol. 2014, 190, 84-96. [CrossRef] [PubMed]

122. Whiteford, H.A.; Degenhardt, L.; Rehm, J.; Baxter, A.J.; Ferrari, A.J.; Erskine, H.E.; Charlson, F.J.; Norman, R.E.; Flaxman, A.D.; Johns, N.; et al. VosT Global burden of disease attributable to mental and substance use disorders: Findings from the Global Burden of Disease Study 2010. Lancet 2013, 382, 1575-1586. [CrossRef]

123. Trinh, P.; Zaneveld, J.R.; Safranek, S.; Rabinowitz, P.M. One Health Relationships between Human, Animal, and Environmental Microbiomes: A Mini-Review. Front. Public Health 2018, 6, 235. [CrossRef] [PubMed]

124. Rostal, M.K.; Ross, N.; Machalaba, C.; Cordel, C.; Paweska, J.T.; Karesha, W.B. Benefits of a one health approach: An example using Rift Valley fever. One Health 2018, 5, 34-36. [CrossRef]

125. Center for Disease Control (CDC). Emerging Infectious Diseases; National Center for Infectious Diseases, Centers for Disease Control and Prevention (CDC): Atlanta, GA, USA, 1995.

126. Malan-Muller, S.; Valles-Colomer, M.; Raes, J.; Lowry, C.A.; Seedat, S.; Hemmings, S.M.J. The Gut Microbiome and Mental Health: Implications for Anxiety- and Trauma-Related Disorders. OMICS 2018, 22, 90-107. [CrossRef]

127. El Samra, G.H. Climate change, food security, food safety and nutrition. Egypt. J. Occup. Med. 2017, 41, 217-236.

128. Wells, J.M.; Brummer, R.J.; Derrien, M.; MacDonald, T.T.; Troost, F.; Cani, P.D.; Theodorou, V.; Dekker, J.; Méheust, A.; de Vos, W.M.; et al. Homeostasis of the gut barrier and potential biomarkers. Am. J. Physiol. Gastrointest. Liver Physiol. 2016, 312, G171-G193. [CrossRef]

129. Galvani, A.P.; Bauch, C.T.; Anand, M.; Singer, B.H.; Levin, S.A. Interactions in population and ecosystem health. Proc. Natl. Acad. Sci. USA 2016, 113, 14502-14506. [CrossRef] [PubMed]

130. Ecosystems and Human Well-Being. Available online: http://apps.who.int/iris/bitstream/handle/10665/ 43354/9241563095.pdf? sequence=1 (accessed on 30 November 2018).

131. Davenport, E.R.; Sanders, J.G.; Song, S.J.; Amato, K.R.; Clark, A.G.; Knight, R. The human microbiome in evolution. BMC Biol. 2017, 15, 127. [CrossRef] [PubMed]

132. Fischer, A.P. Forest landscapes as social-ecological systems and implications for management. Landsc. Urban Plan. 2018, 177, 138-147. [CrossRef]

133. Murtaugh, M.P.; Steer, C.J.; Sreevatsan, S.; Patterson, N.; Kennedy, S.; Sriramarao, P. The science behind One Health: At the interface of humans, animals, and the environment. Ann. N. Y. Acad. Sci. 2017, 1395, 12-32. [CrossRef] [PubMed]

134. Johnson, I.; Hansen, A.; Bi, P. The challenges of implementing an integrated One Health surveillance system in Australia. Zoonoses Public Health 2018, 65, e229-e236. [CrossRef] [PubMed]

135. Wu, H.-J.; Wu, E. The role of gut microbiota in immune homeostasis and autoimmunity. Gut Microb. 2012, 3, 4-14. [CrossRef] [PubMed]

136. Zhao, Y.; Yu, Y.-B. Intestinal microbiota and chronic constipation. SpringerPlus 2016, 5, 1130. [CrossRef] [PubMed]

137. Atlas, R.; Maloy, S. One Health: People, Animals, and the Environment; ASM Press: Washington, DC, USA, 2014; ISBN 978-1555818425. [CrossRef]

138. David, L.A.; Maurice, C.F.; Carmody, R.N.; Gootenberg, D.B.; Button, J.E.; Wolfe, B.E.; Ling, A.V.; Devlin, A.S.; Varma, Y.; Fischbach, M.A.; et al. Diet rapidly and reproducibly alters the human gut microbiome. Nature 2014, 505, 559-563. [CrossRef]

139. Katsnelson, A. Fermented foods offer up microbial model system. Proc. Natl. Acad. Sci. USA 2017, 114, 2434-2436. [CrossRef] 
140. Rabinowitz, P.M.; Pappaioanou, M.; Bardosh, K.L.; Conti, L. A planetary vision for one health. BMJ Glob. Health 2018, 3, e001137. [CrossRef]

141. Nyatanyi, T.; Wilkes, M.; McDermott, H.; Nzietchueng, S.; Gafarasi, I.; Mudakikwa, A.; Kinani, J.F.; Rukelibuga, J.; Omolo, J.; Mupfasoni, D.; et al. Implementing One Health as an integrated approach to health in Rwanda. BMJ Glob. Health 2017, 2, e000121. [CrossRef] [PubMed] 